\title{
Letter:
}

\section{Screening for simple sequence repeat markers in Puccinia striiformis tritici based on genomic sequence*}

\author{
Gang-ming ZHAN ${ }^{1}$, Fu-ping WANG ${ }^{1}$, Huai-yong LUO ${ }^{1}$, Shu-chang JIANG ${ }^{1}$, \\ Wen-ming ZHENG ${ }^{2}$, Li-li HUANG ${ }^{1}$, Zhen-sheng $\mathrm{KANG}^{\dagger 1}$ \\ $\left({ }^{1}\right.$ State Key Laboratory of Crop Stress Biology for Arid Areas and College of Plant Protection, \\ Northwest A\&F University, Yangling 712100, China) \\ $\left({ }^{2}\right.$ State Key Laboratory of Wheat and Maize Crop Science, Collaborative Innovation Center of Henan Grain Crops, \\ College of Life Science, Henan Agricultural University, Zhengzhou 450002, China) \\ †E-mail: kangzs@nwsuaf.edu.cn \\ Received Dec. 23, 2014; Revision accepted Apr. 22, 2015; Crosschecked July 9, 2015
}

\begin{abstract}
Puccinia striiformis f. sp. tritici (Pst) is the obligate biotrophic fungus responsible for stripe rust wheat. In this study, we developed and characterized 20 polymorphic microsatellite markers from the genomic sequence of an isolate of Chinese Pst race CY32. Polymorphism at each simple sequence repeat (SSR) locus was determined using 32 Pst isolates from 7 countries. The number of alleles varied from 2 to 7 across isolates, and the observed and expected heterozygosities ranged from 0.33 to 0.97 (mean 0.62) and 0.23 to 0.73 (mean 0.51), respectively. As expected the genomic SSR markers were more polymorphic than the expressed sequence tag (EST)-SSR markers developed previously. These markers will be more useful for population genetics and molecular genetics studies in Pst.
\end{abstract}

Key words: Microsatellites, Simple sequence repeat, Stripe rust doi: $10.1631 /$ jzus.B1400364

\section{Introduction}

Stripe (or yellow) rust, one of the most destructive diseases of wheat worldwide, is caused by Puccinia striiformis $\mathrm{f}$. sp. tritici (Pst), an obligate fungal pathogen that can disperse over long distances by means of wind-borne urediniospores (Brown and Hovmøller, 2002). The urediniospores and the hyphal stage on wheat are dikaryotic, but at the genetic level Pst behaves as a functional diploid. Pst populations have a high level of diversity at both the avirulence/

\footnotetext{
Corresponding author

* Project supported by the National Basic Research Program (973) of China (No. 2013CB127700), the Special Fund for Agro-Scientific Research in the Public Interest (No. 201303023), the National Natural Science Foundation of China (No. 31371882), and the 111 Project from the Ministry of Education of China (No. B07049)

(1D) ORCID: Gang-ming ZHAN, http://orcid.org/0000-0001-9282-9606

(C) Zhejiang University and Springer-Verlag Berlin Heidelberg 2015
}

virulence (phenotypic) and molecular (genotypic) levels (Mboup et al., 2009; Duan et al., 2010). Genetic variation is created by mutation and recombination, and selection determines the phenotypic frequencies that characterize the populations. As avirulence is dominant to virulence, hidden non-functional mutations of avirulence genes (often referred to as "virulence alleles") are often present in the pathogen populations. In order to evolve from avirulence to virulence, only a single mutation in a heterozygous avirulent individual is required for a change in phenotype from avirulent to virulent, whereas in a homozygous individual a simultaneous double mutation (i.e. the mutation frequency squared) is required. Once the phenotype has changed, the genetic forces of selection and chance determine whether the new variant will survive in the population and at what frequency. Clearly, if a new race is virulent on a 
widely grown previously resistant wheat variety, it will be differentially selected on that variety. Given the potentially huge populations of urediniospores, the likelihood of such a mutant (assuming a mutation rate of $10^{-6}$ ) infecting a resistant variety over time is not negligible. Hence, it is a repeated observation that resistant varieties become susceptible (resistance "break-down") within a few years of being introduced into agriculture (Wellings and McIntosh, 1990; Bayles et al., 2000; Hovmøller et al., 2002). It is also possible that virulent phenotypes may already be present in the pathogen population, but at such low frequencies that they are not detected by routine surveys in the absence of the selective variety (or sometimes varieties). Other ways by which new virulent phenotypes may appear in local national populations are by wind-borne (or human-borne, or even animal- or bird-borne) introduction from outside the region of focus, or by genetic recombination (both sexual and asexual). Asexual variation in cereal fungi (sometimes called "somatic recombination") has been documented (Little and Manners, 1967) in laboratory studies and occasionally shown to be a significant cause of variation in the field (Park and Wellings, 2012). The recent prediction from population studies of the likelihood of sexual recombination in $P s t$ in China (Mboup et al., 2009), and subsequent demonstration of Berberis spp. as an alternative host, firstly for $P$. striiformis f. sp. poae, and subsequently Pst (Jin et al., 2010) in USA, followed by China (Zhao et al., 2013), re-awakened the interest of cereal rust workers internationally to the role of alternative hosts as drivers of phenotypic variation in cereal rust pathogens. The significance of these discoveries is yet to be determined. Studies on population genetics will undoubtedly be vital in future research and the tools for such studies will be avirulence/virulence phenotypes and molecular markers. The idea of applying molecular markers to understanding variation in the stripe rust pathogen is not new. It started with isozyme studies by Newton et al. (1985) who tested earlier conclusions from pathogen avirulence/virulence studies with Pst. Several research groups have developed molecular markers for population genetic studies of Pst (Chen et al., 1993; Shan et al., 1998; Justesen et al., 2002; Roose-Amsaleg et al., 2002; Enjalbert et al., 2005). In order to study Pst populations at the molecular level, simple sequence repeat
(SSR) markers, as one group of robust molecular markers that are multi-allelic, co-dominant, abundant, and highly informative, were developed from complementary DNA (cDNA) and expressed sequence tag (EST) libraries (Enjalbert et al., 2002; Bahri et al., 2009; Chen et al., 2009; Cheng et al., 2012) and were used in population genetic studies (Zhan et al., 2012; Ali et al., 2014b) or in studies of origination and prediction of migratory trajectories (Ali et al., 2014a). However, these markers were limited in number and even uninformative (e.g. in Australian isolates). A recent publication reported 25 polymorphic genomederived SSRs in Australian Pst isolates (Bailey et al., 2013), and these markers were developed using genomic sequence of North American race PST130 (genome size about $64.8 \mathrm{Mb}$ ) published by Cantu et al. (2011) and supplemented with sequence data from collaborators at the Australian National University. A total of 1889 SSR loci were identified in these datasets. Clearly, the genome sequence containing non-transcribed as well as transcribed DNA provides more potential SSR loci than the lower numbers identified in cDNA or EST libraries. Despite this, the numbers of available SSR markers are still limited, and more are needed for future population and potential genetic and mapping studies, especially considering populations with low diversity.

Zheng et al. (2013) have published a betterassembled draft genome sequence of Pst race CY32, one of the currently most dominant races in China, using a "fosmid-to-fosmid" strategy. Compared with the draft genome sequence of PST130, the CY32 has much larger genome size (about $110 \mathrm{Mb}$ ) and potentially more SSR loci. In this study, the objective was to identify and develop additional SSR markers using the genomic sequence of CY32. It was expected that this would enable detection of a greater range of polymorphic loci, and more allelic variation at nonexpressed loci that are not subject to selection. However, we must always keep in mind that Pst mainly propagates by asexual reproduction and that any selection on one single allele (e.g. a virulence allele) will be simultaneous selection for every other allele in that same individual. Such selection with changes in varieties will lead to huge swings in gene frequencies over time as a consequence of selection for just one allele. In this study, we developed and characterized 20 polymorphic genomic SSR markers. 


\section{Materials and methods}

Primers were designed from the DNA sequence isolated from urediniospores of Chinese Pst race CY32 (Zheng et al., 2013). Microsatellite loci were identified by screening the sequence data using the MISA (microsatellite identification tool; http://pgrc. ipk-gatersleben.de/misa/misa.html). A total of 1768 of 4238 scaffolds (41.28\%) retrieved from the genome sequence contained 9682 SSRs. Among the repeats, trinucleotides were the most abundant, accounting for $47.6 \%$ of total repeats, followed by dinucleotides $(47.2 \%)$, tetranucleotides $(3.1 \%)$, pentanucleotides $(1.4 \%)$, and hexanucleotides $(0.81 \%)$. One hundred pairs of primers were designed using Primer 5 software and 32 Pst isolates, introduced from 7 countries and therefore representing different populations (Table 1), were used to verify the polymorphism and allelic variation.

Table 1 Origins of 32 Puccinia striiformis f. sp. tritici isolates used to obtain polymorphic microsatellite loci

\begin{tabular}{ccl}
\hline Host & No. & \multicolumn{1}{c}{ Origin } \\
\hline Bread wheat & 4 & Washington, USA \\
Bread wheat & 3 & Stuttgart, Germany \\
Bread wheat & 4 & Lebanon \\
Bread wheat & 5 & Adana, Turkey \\
Bread wheat & 5 & Tashkent, Uzbekistan \\
Bread wheat & 3 & Morocco \\
Bread wheat & 8 & Sichuan and Gansu, China \\
Total & 32 & \\
\hline
\end{tabular}

Genomic DNA from the 32 isolates was extracted by modified cetyltrimethyl ammonium bromide (CTAB) protocols (Enjalbert et al., 2002; Justesen et al., 2002). Twenty milligrams of urediniospores were placed in a 2-ml centrifuge tube and an equal amount of silica and $200 \mu 12 \%(0.02 \mathrm{~g} / \mathrm{ml}) \mathrm{CTAB}$ $(0.05 \mathrm{~mol} / \mathrm{L} \mathrm{CTAB}, 0.14 \mathrm{~mol} / \mathrm{L} \mathrm{NaCl}, 0.2 \mathrm{~mol} / \mathrm{L}$ Tris$\mathrm{HCl}$ (pH 8.0), $20 \mathrm{mmol} / \mathrm{L}$ ethylene diamine tetraacetic acid (EDTA; $\mathrm{pH} 8.0)$ ) were added to the tube, before milling on ice using a small drill for about $1 \mathrm{~min}$. A further $200 \mu \mathrm{l} 2 \%(0.02 \mathrm{~g} / \mathrm{ml}) \mathrm{CTAB}$ and $5 \mu \mathrm{l}$ proteinase $\mathrm{K}$ were added to the tube, mixed gently and incubated at $65{ }^{\circ} \mathrm{C}$ for $2 \mathrm{~h}$. After adding $700 \mu \mathrm{l} \mathrm{phenol} /$ chloroform/isoamyl alcohol (25:24:1, v/v/v; $\mathrm{pH}>7.8)$, the mixture was vortexed and centrifuged at $14000 \mathrm{r} / \mathrm{min}$ at $4{ }^{\circ} \mathrm{C}$ for $10 \mathrm{~min}$. The upper aqueous phase was added to a new tube, and centrifuged for $10 \mathrm{~min}$ at $12000 \mathrm{r} / \mathrm{min}$ and $4{ }^{\circ} \mathrm{C}$ after adding $300 \mu \mathrm{l}$ chloroform. The upper aqueous phase was placed in a new tube, to which $750 \mu \mathrm{l}$ cool isopropanol was added. The mixture was kept at $-20{ }^{\circ} \mathrm{C}$ for $2 \mathrm{~h}$ before centrifuging for $30 \mathrm{~min}$ at $12000 \mathrm{r} / \mathrm{min}$ and $4{ }^{\circ} \mathrm{C}$. The pellet was washed three times with $95 \%$ ethanol and then dissolved in $50 \mu 11 \times$ Tris-EDTA (TE) buffer after drying. The DNA concentration was measured using a ND-1000 spectrophotometer (Bio-Rad, Hercules, CA, USA) and diluted to $50 \mathrm{ng} / \mu \mathrm{l}$ for later polymerase chain reaction (PCR) amplification. PCR was carried out in $25 \mu \mathrm{l}$ volumes containing $2.0 \mu \mathrm{l}$ of template DNA, $2.5 \mu$ l of $10 \times$ reaction buffer $\left(\mathrm{Mg}^{2+}\right.$ free), $2.0 \mu \mathrm{l}$ of $\mathrm{Mg}^{2+}$ ( $\left.25 \mathrm{mmol} / \mathrm{L}\right), 2.0 \mu \mathrm{l}$ of dNTPs $(2.5 \mathrm{mmol} / \mathrm{L}), 1 \mu \mathrm{l}$ of each primer $(10 \mathrm{mmol} / \mathrm{L}), 0.2 \mu \mathrm{l}$ Taq DNA polymerase ( $5 \mathrm{U} / \mu \mathrm{l}$, TaKaRa, Japan), and $14.3 \mu$ of double-distilled water. The PCR conditions were: denaturation at $95{ }^{\circ} \mathrm{C}$ for $4 \mathrm{~min}, 35$ cycles at $94{ }^{\circ} \mathrm{C}$ for $45 \mathrm{~s}, 60^{\circ} \mathrm{C}$ (varies for each primer pair) for $45 \mathrm{~s}, 72{ }^{\circ} \mathrm{C}$ for $45 \mathrm{~s}$, then $72{ }^{\circ} \mathrm{C}$ for $10 \mathrm{~min}$. After amplification, $5 \mu \mathrm{l}$ of $6 \times$ formamide-loading buffer was added to each mixture which was then denatured for $5 \mathrm{~min}$ at $95^{\circ} \mathrm{C}$. A volume of $5 \mu \mathrm{l}$ of each denatured PCR product was used to detect polymorphism on a $6 \%(0.06 \mathrm{~g} / \mathrm{ml})$ denaturing polyacrylamide gel and $4 \mu \mathrm{l}$ of DNA marker was added to each gel to estimate the size of SSR bands. Gel preparation, electrophoresis, and silver-staining were performed under protocols described in Chen et al. (1998).

\section{Results and discussion}

Ninety-four primer pairs successfully produced bands when tested on 32 Pst isolates, but only 20 primer pairs generated SSR polymorphisms. POPEGENE V1.21 (CIFOR and University of Alberta, Canada) was used to calculate the number of alleles. The observed $\left(H_{\mathrm{o}}\right)$ and expected $\left(H_{\mathrm{e}}\right)$ heterozygosities were calculated using Cervus V2.0 software (Slate et al., 2000). PowerMarker V3.25 (Liu and Muse, 2005) was used to test the deviation from a Hardy-Weinberg equilibrium and the linkage disequilibrium at each locus and to calculate the polymorphic information content (PIC) value (Botstein et al., 1980). The total number of alleles per locus ranged from 2 to 7 with a mean of 3.25 (Table 2). The total $H_{\mathrm{o}}$ and $H_{\mathrm{e}}$ ranged 
Table 2 Characteristics of 20 genomic SSR markers developed from Pst race CY32 using 32 Pst isolates

\begin{tabular}{|c|c|c|c|c|c|c|c|c|c|}
\hline Locus & Primer sequence (5'-3') & Repeat motif & $\begin{array}{c}T_{\mathrm{m}} \\
\left({ }^{\circ} \mathrm{C}\right)\end{array}$ & $\begin{array}{l}\text { Allele No., } \\
\text { size (bp) }\end{array}$ & $H_{\mathrm{o}}$ & $H_{\mathrm{e}}$ & $\begin{array}{l}\text { HWE test } \\
P \text { value }\end{array}$ & PIC & $\begin{array}{c}\text { GenBank } \\
\text { accession No. }\end{array}$ \\
\hline WSR3 & $\begin{array}{l}\text { F: GTCCTGGGTTCATTCTGGGG } \\
\text { R: GTCGAATCCGCGTGTAAACG }\end{array}$ & $(\mathrm{TTA})_{5}$ & 62 & $\begin{array}{c}2, \\
139-144\end{array}$ & 0.78 & 0.54 & 0.059 & 0.19 & KI516648.1 \\
\hline WSR7 & $\begin{array}{l}\text { F: CAGGGGGAAAGCAAAAACCG } \\
\text { R: GATGGCACTGATCGGATCGT }\end{array}$ & $(\mathrm{AAC})_{5}$ & 60 & $\begin{array}{c}2 \\
132-137\end{array}$ & 0.35 & 0.23 & 0.059 & 0.19 & KI516377.1 \\
\hline WSR12 & $\begin{array}{l}\text { F: ACTGTGAGCTCGACAACCAG } \\
\text { R: GACATCATCACCCCCAAGCA }\end{array}$ & $(\mathrm{ACA})_{5}$ & 63 & $\begin{array}{c}2, \\
180-183\end{array}$ & 0.63 & 0.47 & 0.079 & 0.34 & KI517085.1 \\
\hline WSR14 & $\begin{array}{l}\text { F: AAGCAGTTCGTTTGCAGCTG } \\
\text { R: TCAGAGACTGGCAGGGCTAT }\end{array}$ & $(\mathrm{GTT})_{6}$ & 60 & $\begin{array}{c}4, \\
246-252\end{array}$ & 0.36 & 0.53 & 0.472 & 0.37 & KI517066.1 \\
\hline WSR22 & $\begin{array}{l}\text { F: GCCCGAGTGAGTACGATGAG } \\
\text { R: GCCCACTCGAGATTCCCAAA }\end{array}$ & $(\mathrm{GA})_{9}$ & 63 & $\begin{array}{c}4, \\
209-215\end{array}$ & 0.38 & 0.55 & 0.045 & 0.35 & KI515798.1 \\
\hline WSR23 & $\begin{array}{l}\text { F: CGAATGCCCAGAAGGAGGTT } \\
\text { R: GGTCCGCCGAGACATCTAAG }\end{array}$ & $(\mathrm{GAA})_{5}$ & 60 & $\begin{array}{c}2 \\
210-213\end{array}$ & 0.93 & 0.62 & 0.536 & 0.34 & KI515808.1 \\
\hline WSR31 & $\begin{array}{l}\text { F: GTGGTGGGATGTCACATCGT } \\
\text { R: GCTACGCTTCGAGCTGAGAT }\end{array}$ & $(\mathrm{CAT})_{8}$ & 60 & $\begin{array}{c}5 \\
146-154\end{array}$ & 0.63 & 0.47 & 0.484 & 0.37 & KI517043.1 \\
\hline WSR38 & $\begin{array}{l}\text { F: CTGGGTTTTTGCGTGGTCTG } \\
\text { R: GTCGGCCCAAAATTGCACTT }\end{array}$ & $(\mathrm{AT})_{11}$ & 58 & $\begin{array}{c}3, \\
211-215\end{array}$ & 0.92 & 0.73 & 0.491 & 0.36 & KI517050.1 \\
\hline WSR39 & $\begin{array}{l}\text { F: CCCTCTGGGCTTGTCTCAAG } \\
\text { R: CGACTAGGGTGGGTTGTGAC }\end{array}$ & $(\mathrm{TG})_{6}$ & 60 & $\begin{array}{c}3 \\
252-256\end{array}$ & 0.37 & 0.23 & 0.218 & 0.19 & KI517049.1 \\
\hline WSR44 & $\begin{array}{l}\text { F: AGGCCCCAGGAACACAAAAA } \\
\text { R: TCACACACGCTCCACAGTAC }\end{array}$ & $(\mathrm{GT})_{6}$ & 61 & $\begin{array}{c}3, \\
186-192\end{array}$ & 0.48 & 0.53 & 0.415 & 0.51 & KI516146.1 \\
\hline WSR51 & $\begin{array}{l}\text { F: GTTGGAGCTCCTCTGCCAAT } \\
\text { R: GCCAATGGCTATCAAGTGCG }\end{array}$ & $(\mathrm{GATCG})_{5}$ & 59 & $\begin{array}{c}3, \\
283-290\end{array}$ & 0.33 & 0.50 & 0.320 & 0.35 & KI516031.1 \\
\hline WSR54 & $\begin{array}{l}\text { F: GAGCGTTGGGTTTTGGGTTC } \\
\text { R: ACCATCCTCACTCTCGTCGA }\end{array}$ & $(\mathrm{AGC})_{7}$ & 60 & $\begin{array}{c}5, \\
294-301\end{array}$ & 0.97 & 0.79 & 0.005 & 0.34 & KI516036.1 \\
\hline WSR62 & $\begin{array}{l}\text { F: CCCTCCCATCCAGCACAAAT } \\
\text { R: CGTTGTTGAACAGCCCTTGG }\end{array}$ & $(\mathrm{GAT})_{6}$ & 63 & $\begin{array}{c}7 \\
277-293\end{array}$ & 0.50 & 0.44 & 0.468 & 0.30 & KI515824.1 \\
\hline WSR70 & $\begin{array}{l}\text { F: GCAAGGGACTCAACTCGACA } \\
\text { R: CTCCGCGACACTCTCTCATC }\end{array}$ & $(\mathrm{GA})_{9}$ & 62 & $\begin{array}{c}3 \\
177-182\end{array}$ & 0.86 & 0.65 & 0.263 & 0.56 & KI515815.1 \\
\hline WSR79 & $\begin{array}{l}\text { F: AGCACAACGTCCTTCTAGCC } \\
\text { R: TGTTGAGGACCGACGAGTTG }\end{array}$ & $(\mathrm{TCA})_{5}$ & 60 & $\begin{array}{c}3, \\
296-301\end{array}$ & 0.63 & 0.49 & 0.215 & 0.34 & KI515805.1 \\
\hline WSR85 & $\begin{array}{l}\text { F: GCTGGTACCTCTGGCCATTT } \\
\text { R: GGAGGAGGATTTGGTGGTGG }\end{array}$ & $(\mathrm{CAC})_{7}$ & 60 & $\begin{array}{c}3, \\
208-212\end{array}$ & 0.50 & 0.47 & 0.487 & 0.30 & KI516390.1 \\
\hline WSR90 & $\begin{array}{l}\text { F: GTCGTTCAGTTTCGATCGCG } \\
\text { R: ATCTCTCACTCCAGCCCACT }\end{array}$ & $(\mathrm{GTT})_{7}$ & 59 & $\begin{array}{c}3, \\
283-288\end{array}$ & 0.50 & 0.42 & 0.385 & 0.39 & KI515998.1 \\
\hline WSR91 & $\begin{array}{l}\text { F: AAGGGGAGTGGCGAATGAAG } \\
\text { R: CAGACACGGTCTCGACAACA }\end{array}$ & $(\mathrm{GA})_{8}$ & 61 & $\begin{array}{c}2 \\
201-206\end{array}$ & 0.75 & 0.50 & 0.461 & 0.36 & KI517179.1 \\
\hline WSR95 & $\begin{array}{l}\text { F: GCTGTTCATTGCTGGTGGTG } \\
\text { R: GCCAGCCAACTGCAAAATCA }\end{array}$ & $(\mathrm{GTG})_{5}$ & 60 & $\begin{array}{c}3 \\
295-299\end{array}$ & 0.81 & 0.60 & 0.441 & 0.31 & KI516269.1 \\
\hline WSR98 & $\begin{array}{l}\text { F: TCCAACTCATCTATCGGCGC } \\
\text { R: TAGACTATGCGTTCGACGGC }\end{array}$ & $(\mathrm{TC})_{9}$ & 61 & $\begin{array}{c}4 \\
178-180\end{array}$ & 0.63 & 0.49 & 0.154 & 0.34 & KI517167.1 \\
\hline Mean & & & & 3.25 & 0.62 & 0.51 & & 0.34 & \\
\hline
\end{tabular}

F, forward; R, reverse; $H_{\mathrm{o}}$, observed heterozygosities; $H_{\mathrm{e}}$, expected heterozygosities; HWE, Hardying-Weinberg equilibria; PIC, polymorphic information content. PIC value $<0.05$ indicates significant departure from HWE

from 0.33 to 0.97 (mean 0.62 ) and from 0.23 to 0.73 (mean 0.51), respectively. The PIC across all loci varied from 0.19 to 0.56 , with an average of 0.34 . No significant linkage disequilibrium $(P<0.01)$ was detected among the 20 loci. All loci showed HardyWeinberg equilibrium except WSR51 $(P<0.05)$, which was likely due to limited sample size or the result of null alleles. The reason that the $H_{\mathrm{e}}$ was higher than $H_{\mathrm{o}}$ at loci WSR14, WSR22, and WSR44 may be the presence of sexual recombination in some of the tested populations, in which the isolates were sampled and null alleles.

As expected, SSR markers in Pst based on the genome sequence, appear to be more polymorphic.
The numbers of alleles, $H_{\mathrm{o}}$, and $H_{\mathrm{e}}$ were higher than those reported in earlier studies that targeted ESTSSRs (Enjalbert et al., 2002; Bahri et al., 2009; Chen et al., 2009; Cheng et al., 2012). In the study of Enjalbert et al. (2002), the number of alleles ranged from 2 to 5 with a mean 2.75. In the study of Bahri et al. (2009), the $H_{\mathrm{e}}$ ranged from 0.07 to 0.77 , and in the studies of Chen et al. (2009) and Cheng et al. (2012), the $H_{\mathrm{o}}$ and $H_{\mathrm{e}}$ ranged from 0.12 to 0.78 and 0.08 to 0.45 , and 0.14 to 0.87 and 0.01 to 0.67 , respectively. In our study, the number of alleles ranged from 2 to 7 , and the $H_{\mathrm{o}}$ and $H_{\mathrm{e}}$ ranged from 0.33 to 0.97 and 0.23 to 0.73 , respectively. These results confirm that microsatellite loci obtained from the genomic sequence are more 
diverse than EST-SSRs, and therefore better for studies on genetic diversity in P. striiformis f. sp. tritici.

\section{Conclusions}

Despite the limited number of isolates measured in this study, the polymorphisms found for the 20 microsatellites developed by the whole genome screening demonstrated that these markers should be highly effective for studying genetic diversity, evolution, genetic segregation, and mapping avirulence genes in Pst population genetics in the future.

\section{Acknowledgements}

We sincerely thank Prof. Robert MCINTOSH, University of Sydney, Australia, for revising this paper.

\section{Compliance with ethics guidelines}

Gang-ming ZHAN, Fu-ping WANG, Huai-yong LUO, Shu-chang JIANG, Wen-ming ZHENG, Li-li HUANG, and Zhen-sheng KANG declare that they have no conflict of interest.

This article does not contain any studies with human or animal subjects performed by any of the authors.

\section{References}

Ali, S., Gladieux, P., Rahman, H., et al., 2014a. Inferring the contribution of sexual reproduction, migration and off-season survival to the temporal maintenance of microbial populations: a case study on the wheat fungal pathogen Puccinia striiformis f. sp. tritici. Mol. Ecol., 23(3):603-617. [doi:10.1111/mec.12629]

Ali, S., Gladieux, P., Leconte, M., et al., 2014b. Origin, migration routes and worldwide population genetic structure of the wheat yellow rust pathogen Puccinia striiformis f. sp. tritici. PLoS Pathog., 10(1):e1003903. [doi:10.1371/ journal.ppat.1003903]

Bahri, B., Leconte, M., de Vallavieille-Pope, C., et al., 2009. Isolation of ten microsatellite loci in an EST library of the phytopathogenic fungus Puccinia striiformis f. sp. tritici. Conserv. Genet., 10(5):1425-1428. [doi:10.1007/s10592008-9752-5]

Bailey, J., Karaoglu, H., Wellings, C.R., et al., 2013. Isolation and characterization of 25 genome-derived simple sequence repeat markers for Puccinia striiformis f. sp tritici. Mol. Ecol. Resour., 13(4):760-762. [doi:10.1111/17550998.12121]

Bayles, R.A., Flath, K., Hovmøller, M.S., et al., 2000. Breakdown of the Yr17 resistance to yellow rust of wheat in northern Europe - a case study by the yellow rust sub-group of COST 817. Agronomie, 20(7):805-811. [doi:10.1051/agro:2000176]
Botstein, D., White, R.L., Skolnick, M., et al., 1980. Construction of a genetic linkage map in man using restriction fragment length polymorphisms. Am. J. Hum. Genet., 32(3):314-331.

Brown, J.K.M., Hovmøller, M.S., 2002. Epidemiology aerial dispersal of pathogens on the global and continental scales and its impact on plant disease. Science, 297(5581): 537-541. [doi:10.1126/science.1072678]

Cantu, D., Govindarajulu, M., Kozik, A., et al., 2011. Next generation sequencing provides rapid access to the genome of Puccinia striiformis $\mathrm{f}$. sp. tritici, the causal agent of wheat stripe rust. PLOS ONE, 6(8):e24230. [doi:10. 1371/journal.pone.0024230]

Chen, C.Q., Zheng, W.M., Buchenauer, H., et al., 2009. Isolation of microsatellite loci from expressed sequence tag library of Puccinia striiformis f. sp. tritici. Mol. Ecol. Resour., 9(1):236-238. [doi:10.1111/j.1755-0998.2008. 02423.x]

Chen, X.M., Line, R.F., Leung, H., 1993. Relationship between virulence variation and DNA polymorphism in Puccinia striiformis. Phytopathology, 83(12):1489-1497. [doi:10.1094/Phyto-83-1489]

Chen, X.M., Line, R.F., Leung, H., 1998. Genome scanning for resistance-gene analogs in rice, barley and wheat by high-resolution electrophoresis. Theor. Appl. Genet., 97(3): 345-355. [doi:10.1007/s001220050905]

Cheng, P., Chen, X.M., Xu, L.S., et al., 2012. Development and characterization of expressed sequence tag-derived microsatellite markers for the wheat stripe rust fungus Puccinia striiformis f. sp. tritici. Mol. Ecol. Resour., 12(4): 779-781. [doi:10.1111/j.1755-0998.2012.03155.x]

Duan, X.Y., Tellier, A., Wan, A., et al., 2010. Puccinia striiformis $\mathrm{f}$. sp. tritici presents high diversity and recombination in the over-summering zone of Gansu, China. Mycologia, 102(1):44-53. [doi:10.3852/08-098]

Enjalbert, J., Duan, X.Y., Vautrin, D., et al., 2002. Isolation of twelve microsatellite loci, using an enrichment protocol, in the phytopathogenic fungus Puccinia striiformis $\mathrm{f} . \mathrm{sp}$. tritici. Mol. Ecol. Notes, 2(4):563-565. [doi:10.1046/j. 1471-8286.2002.00322.x]

Enjalbert, J., Duan, X.Y., Leconte, M., et al., 2005. Genetic evidence of local adaptation of wheat yellow rust (Puccinia striiformis f. sp. tritici) within France. Mol. Ecol., 14(7):2065-2073. [doi:10.1111/j.1365-294X.2005.02566.x]

Hovmøller, M.S., Justesen, A.F., Brown, J.K.M., 2002. Clonality and long-distance migration of Puccinia striiformis $\mathrm{f}$. sp. tritici in North-west Europe. Plant Pathol., 51(1): 24-32. [doi:10.1046/j.1365-3059.2002.00652.x]

Jin, Y., Szabo, L.J., Carson, M., 2010. Century-old mystery of Puccinia striiformis life history solved with the identification of Berberis as an alternate host. Phytopathology, 100(5):432-435. [doi:10.1094/PHYTO-100-5-0432]

Justesen, A.F., Ridout, C.J., Hovmøller, M.S., 2002. The recent history of Puccinia striiformis f. sp. tritici in Denmark as revealed by disease incidence and AFLP markers. Plant Pathol., 51(1):13-23. [doi:10.1046/j.0032- 
0862.2001.00651.x]

Little, R., Manners, J.G., 1967. Production of new physiologic races in Puccinia striiformis (yellow rust) by heterokaryosis. Nature, 213(5074):422. [doi:10.1038/213422a0]

Liu, K., Muse, S.V., 2005. PowerMarker: an integrated analysis environment for genetic marker analysis. Bioinformatics, 21(9):2128-2129. [doi:10.1093/bioinformatics/bti282]

Mboup, M., Leconte, M., Gautier, A., et al., 2009. Evidence of genetic recombination in wheat yellow rust populations of a Chinese oversummering area. Fungal Genet. Biol., 46(4):299-307. [doi:10.1016/j.fgb.2008.12.007]

Newton, A.C., Caten, C.E., Johnson, R., 1985. Variation for isozymes and double-stranded RNA among isolates of Puccinia striiformis and two other cereal rusts. Plant Pathol., 34(2):235-247. [doi:10.1111/j.1365-3059.1985. tb01355.x]

Park, R.F., Wellings, C.R., 2012. Somatic hybridization in the Uredinales. Annu. Rev. Phytopathol., 50(1):219-239. [doi:10.1146/annurev-phyto-072910-095405]

Roose-Amsaleg, C., de Vallavieille-Pope, C., Brygoo, Y., et al., 2002. Characterisation of a length polymorphism in the two intergenic spacers of ribosomal RNA in Puccinia striiformis f. sp. tritici, the causal agent of wheat yellow rust. Mycol. Res., 106(8):918-924. [doi:10.1017/S095375 6202006251]

Shan, W.X., Chen, S.Y., Kang, Z.S., et al., 1998. Genetic diversity in Puccinia striiformis Westend. f. sp. tritici revealed by pathogen genome-specific repetitive sequence. Can. J. Botany, 76(4):587-595. [doi:10.1139/ b98-035]

Slate, J., Marshall, T.C., Pemberton, J.M., 2000. A retrospective assessment of the accuracy of the paternity inference program CERVUS. Mol. Ecol., 9(6):801-808. [doi:10. 1046/j.1365-294X.2000.00930.x]

Wellings, C.R., McIntosh, R.A., 1990. Puccinia striiformis f. sp. tritici in Australia: pathogenic changes during the first 10 years. Plant Pathol., 39(2):316-325. [doi:10.1111/j. 1365-3059.1990.tb02509.x]

Zhan, G.M., Chen, X.M., Kang, Z.S., et al., 2012. Comparative virulence phenotypes and molecular genotypes of Puccinia striiformis $\mathrm{f}$. sp. tritici, the wheat stripe rust pathogen in China and the United States. Fungal Biol., 116(6): 643-653. [doi:10.1016/j.funbio.2012.03.004]

Zhao, J., Wang, L., Wang, Z.Y., et al., 2013. Identification of eighteen Berberis species as alternate hosts of Puccinia striiformis f. sp. tritici and virulence variation in the pathogen isolates from natural infection of barberry plants in China. Phytopathology, 103(9):927-934. [doi:10.1094/ PHYTO-09-12-0249-R]

Zheng, W.M., Huang, L.L., Huang, J.Q., et al., 2013. High genome heterozygosity and endemic genetic recombination in the wheat stripe rust fungus. Nat. Commun., 4:2673. [doi:10.1038/ncomms3673]

\section{中文概要}

题 目: 基于小麦条锈菌基因组序列篮选简单重复序列 标记

目 的: 筛选得到多态性好、扩增稳定的条锈菌微卫星标 记, 以期更好应用于小麦条锈病菌的群体遗传学 研究。

创新点: 基于条锈菌基因组设计了 100 对候选简单重复序 列 (SSR) 引物, 最终筛选得到 20 对多态性好并 且扩增稳定的微卫星标记。

方 法: 基于条锈菌 100 个组装序列用 Primer 5 软件设计 了 100 对 SSR 引物用于检测来自 7 个国家的 32 个菌系, 最终篮选得到 20 对较好的微卫星标记 (表 2)。

结 论: 基于基因组序列篮选得到的 20 对微卫星标记将 会在小麦条锈菌群体遗传研究中得到广泛应用。

关键词: 微卫星标记; 简单重复序列; 小麦条锈菌 